\title{
Establishment of a New Hereditary-cataract Mouse (CSM) Strain Derived from SENCAR Mouse
}

\author{
Tsuyoshi SATO, Tatsuya MIYAI, Isamu AKAIKE, Mamoru TOGASHI \\ Misao KOJIMA and Michio OKAMOTO
}

Drug Derelopment Laboratories, CHUGAI Pharmaceutical Co., Ltd. Takada 3-41-8, Toshima-ku, Tokyo 171, Japan

(Received 28 October 1987/Accepted 1 May 1988)

\begin{abstract}
A mouse representing a new hereditary-cataract strain was found in a mouse colony and a new line was established strain CSM. These mice were investigated genetically, histologically and biochemically. The results suggested that this cataract was apparently inherited through two recessive autosomal genes. Histologically the denucleation process of lens fibers was abnormal and small vacuoles appeared in the equatorial region of the lens cortex at 12 days. Biochemically, insoluble protein and sodium increased in the lens with age.
\end{abstract}

\section{SENCAR 系マウスに見いだされた遺伝性白内障モデル (CSM 系) について}

佐藤毅司・宮井達也・赤池勇

富樫守·小島操・岡本道生

中外製薬秼開発研究所実験動物センター

SENCAR 系マウスは, Boutwell, Slagaらにより樹立 された皮癌好発系のアルビノ・マウスである。起源は “Rockland all purpose mice” よりジメチルベンッアン トラセン (DMBA) とクロトン油の 2 段階発癌法によ りパピローマ好発系として選抜育種されたSTS (skin tumor susceptible) 系マウスで, その後, 繁殖率改善の ため, DMBA と TPA (12-O-tetradecanoylphorbol13-acetate）による皮凊癌誘発の感受性の高いととを確 認された CD-1(ICR Charles River)系の雌と交配し, 選抜されたのが SENCAR 系マウスである。その後あ繁 殖率の低下を避けるため, 兄妹交配による近交化を避け, クローズドコロニーとして維持されてきている $[12] 。$
現在 SENCAR 系マウスの大規模なコロニーは, Oak Ridge 国立研究所にあり, 当研究所には, 1981年に東京 大学医科学研究所 (黒木教授) を介して導入された。導 入後は, 特に皮凊癌好発という特質にはこだわらず, ク ローズドコロニーとして維持されてきたてとにより隠さ れている遺伝子の発現も期待して兄妹交配を行った。こ の過程で 1 ペアより巨大結腸症 (Mega colon) が 発症 し，てれについては遺伝性のものであることが確認され， 当研究所で MSM 系と命名され, 現在 F 10 代に至っ ている。

白内障は, SENCAR 系のF 4 代で一部の個体に見い だされ, その後, 発症個体の選抜交配により症状の固定 
を試み, 選抜交配開始後 F 5 代目で全例に白内障が発症 するようになり，CSM 系と命名した。

マウスにおける遗伝性白内障の報告は, 老人性白内障 のモデルである Emory マウス[10], 若年性白内障のモ デルである Nakano-cataract マウス（以下 Cac マウ ス) $[2,4,5,6,9]$ 等を始めとしていくつか知られて いる。また，ヒトでは先天性白内障は，小児視覚障害の 4 大原因の一つであり, 疫学・先天異常学・遗伝学・小 児医学等それぞれの立場で研究が進められてきた。しか しながら, 先天性白内障の原因は未だ明らかではなく, 発症時期あ出生時より思春期にわたり幅広く，水晶体の 混濁の部位, 程度, 形状等む様々である。乙のように白 内障の病態その屯のが一定ではなく, 病因解明を行うに は，種々の白内障モデルを用いた検討が，今後とも重要 と考え，との系統 (以下, CSM 系マウス) の育種を試 み, 発症状況, 水晶体の生化学的変化, 病理学的変化, 遗伝様式等について検討したので報告する。

\section{材料およひ方法}

1. 供試動物押よび飼育条件：CSM, IV CS, DBA / 2 系マウスの 3 系統を使用した。動物室は, 温度 $24 \pm 2^{\circ} \mathrm{C}$, 湿度 $50 \sim 60 \%$, 換気回数 $12 \sim 15$ 回 $/ \mathrm{hr}$. で, 照明時間は, 5 時点灯，19時消灯の14時間照明とした。動物は，ポリ カーボネイト製マウスケージで飼育し，飼料（CA-1 ・ 日本クレア）および飲料水（水道水と井水の混合水）は 自由摄取とした。

2. 水晶体の観察および写真撮影：散瞳剂（ミドリン

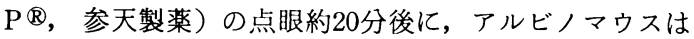
肉眼により, 有色マウスは, 暗室内で眼底カメラ（コー ワ RC-2 眼底カメラ）を用いて両眼を観察し必要に応じ て写真撮影を行った。

3. グレード分けおよび進行状況の判定：水晶体の混 濁部分の大きさから，発症状態を以下の 4 段階に分けた。 グレード 0; 未発症

グレード 1 ; 水晶体の混濁 $1 / 3$ まで

グレード $2 ;$ 水晶体の混濁 $1 / 3$ から $2 / 3$ まで

グレード 3 ; 水晶体の湜濁 $2 / 3$ 以上

白内障の進行状況は，CSM 系マウス26匹の雨眼につ いて肉眼的に観察し，観察日秢は，25日齢打よび30日秢, 以後10日每に 130 日秢まで継続的に行った。

4. 組織学的検査：グレード別病変については，それ ぞれ 2 ないし 3 匹の発症例の眼球を採取し，10\%リン酸 緩衝木 マリンで固定後, パラフィン包埋を行い, $5 \mu \mathrm{m}$
の切片を作成し，ヘマトキシリン・エオジン (H-E) 染 色後, 組織学的検查を行った。

白内障初期病変の観察は, CSM 系マウスの 6 および 12 日齢各 2 匹，対照として同じアルビノマウスである $\mathrm{V}$ CS 系マウスの 6 日齢 2 匹，12日齢 1 匹より材料を採取 した。エーテル屠殺後, 頭皮を除去し, 頭部を 1 週間 10 \% リン酸緩衝ホルマリン溶液に，浸清固定後，脱灰液 （5\% EDTA 液，ph. 6.5〜7）に3 日間浸し，カルシウ ムを除去した。その後, 常法によりパラフィン包埋を行 い, $5 \mu \mathrm{m}$ の切片を作成後, H-E 染色を行い, 組織学的 観察を行った。

5. 生化学的検查 : CSM 系マウスの $1,2,3,5,8$, 12 週榆の雌（6〜10匹）より眼球を採取し水晶体を取り 出し, 重量測定後, 凍結乾燥機仁上り 24 時間乾燥処置を 施し, その後重量を再測定し, 乾燥前後の重量の差を水 分含量とした。

水溶性蛋白含量, 不溶性蛋白含量, $\mathrm{Na}^{+}, \mathrm{K}^{+}$量は, 同 じく $1,2,3,5,8,12$ 週秢の雄 $(5 \sim 14 匹)$ の水晶体 を用い, 水溶性蛋白含量, 不溶性蛋白含量は, Lowry 法により, $\mathrm{Na}^{+}, \mathrm{K}^{+}$量は, 炎光光度計（日立 775-A 型）により測定した。

6. 交配実験：白内障発症の遗伝様式を検討するため, アルビノマウスである IV CS 系マウスおよび有色マウ スである $\mathrm{DBA} / 2$ 系マウスとの間で, 交配実験を行い, 白内障の有無は，それぞれ下記の日齢または月齢で検䍒 し, 最終的な判定を行った。

$$
\begin{aligned}
& \text { (IV CS } \times \text { CSM) F } 1 \quad 60 \text { 日踰 } \\
& \text { [(IV CS } \times \text { CSM }) \mathrm{F} 1 \times \mathrm{CSM}] \quad 60 \text { 日齡 } \\
& (\mathrm{DBA} / 2 \times \mathrm{CSM}) \mathrm{F} 1 \quad 7 \sim 9 \text { 力月齢 } \\
& \text { [(DBA } / 2 \times \mathrm{CSM}) \mathrm{F} 1 \times \mathrm{CSM}] \quad 7 \sim 9 \text { 力月齢 }
\end{aligned}
$$

IV CS 系之の交配では, 産仔はすべてアルビノとなる ため, 肉眼で判定可能であったが, $\mathrm{DBA} / 2$ 系との交配 では有色眼となり, 肉眼での判定が困難であったため, 水晶体を取り出し, 実体顕微鏡下で検査し判定した。

\section{成}

$\mathrm{CSM}$ 系は, 開眼 (12日齢) 後, 比較的早期飞水晶体 の混濁が認められる。Fig. 1 亿，兄妹交配を始めてか らの 1 家系を示した。F 4 代までは，白内障を発症しな い個体あるいは片眼にしか発症しない個体も見られたが， F 5 代以後は， 8 週粭までにほぼ全例が, 両眼に白内障 を発症するようになった。しかしながら, 症状は左右対 称には現れず, 両眼の間に差がみられ, 混濁の程度, 形 


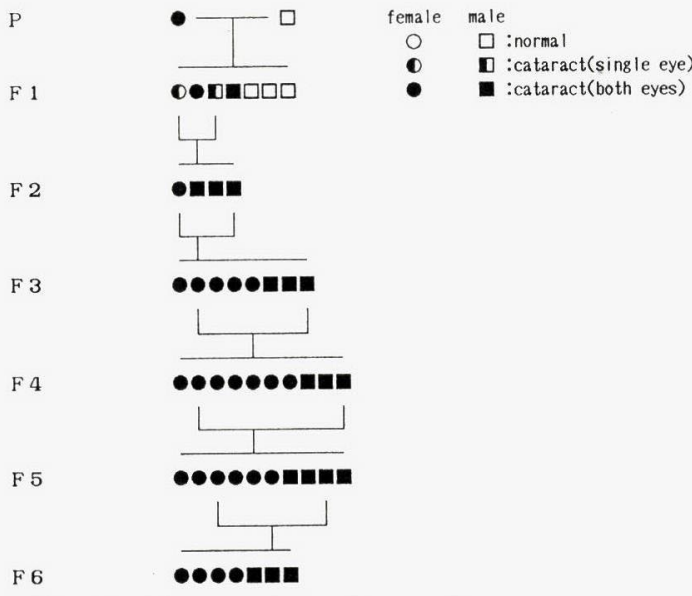

Fig. 1. Part of the pedigree of cataract mouse (CSM)

Table 1. Grade distribution of cataract from 25 days to 130 days

\begin{tabular}{lcrrr}
\hline \multicolumn{5}{c}{ Age (days) } \\
\hline Grade & \multicolumn{1}{c}{25} & \multicolumn{1}{c}{50} & 100 & 130 \\
\hline 0 & $11.5(\%)$ & 7.7 & 5.8 & 5.8 \\
1 & 59.6 & 40.4 & 26.9 & 25.0 \\
2 & 25.0 & 25.0 & 19.2 & 11.5 \\
3 & 3.8 & 26.9 & 48.1 & 57.7 \\
$\mathrm{n}=52$ & & & &
\end{tabular}

状も様々で，こうした傾向は兄妹交配を継続しても収束 しなかった。

25日跲から 130 日齢における白内障のグレード別成績 を Table 1 に示した。最初の観察日である25日㱓では, グレード $0 \sim 3$ と様々であり，個体別にみてあ左右のバ ラッキがかなり大きいが，白内障としては軽度のグレー ド 1 が59.6\%と過半数を占めた。その後50日，100日齢 と加龄に伴い白内障のグレードは進行し, 最終観察日で ある 130 日龄では,グレード 1 は $25.0 \%$ に減少し，替わ って最も重度であるグレード 3 が57.7\% と著しく増加し た。このように全体としては加秢に伴い白内障病変は進 行する傾向にあったが，検査した 52 例の眼球のうち 25 日 齢でグレード 1 と判定されたまま, その後の病変の進行 が見られず，130日歯に至ってもグレード 1 と判定され たものが10例（19.2\%）認められた。

典型的な白内障の肉眼所見を Fig. 2 に示した。 組織学的な变化としては, Fig. 3 に示したように,

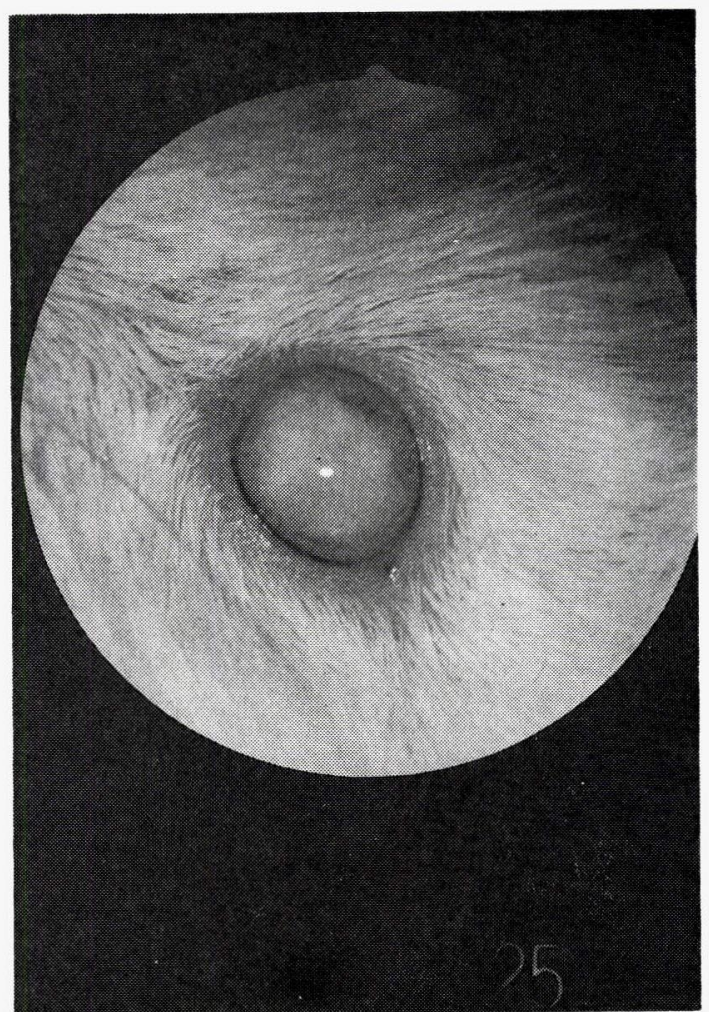

Fig. 2. Gross appearance of cataract in this mouse strain

赤道部から伸長していく水晶体線維の核が，IV CS 系マ ウスでは水晶体中心部に向かうに連れて明膫な核濃縮像 を示した後, 脱核していくのに対し，CSM 系マウスで は，核の円形均質化までは類似の経過を示すが，その後， 明瞭な核濃縮像を示さずに好酸性円形物質となり，エオ ジン好性の水晶体線維の中へ埋むれていくような像とし て捉えられた。このため，CSM 系に比べて IV CS 系 マウスの方が, 水晶体中心近くまで核クロマチンと思わ れる好塩基性顆粒が散在しているのが観察された。

12日齢以後では, 場所は一定ではないが Fig. 4 に示 すような赤道部前後の皮質部浅層で小空胞の発生がみら れ，こうした小空胞は IV CS 系でも僅かに見られるも のの, CSM 系でより強く集中的に認められた。

グレード 3 以上の水晶体では, 固有の構造は失われ, 水晶体線維は, 互いの境界が不明瞭になり，全体に均質 無構造となった不定形物質中に, 空胞あるいは核ないし 細胞の崩壊物と思われる好塩基性顆粒が散在的に認めら れ, 多くの例では, 水晶体核の後極側からの脱出像も認 


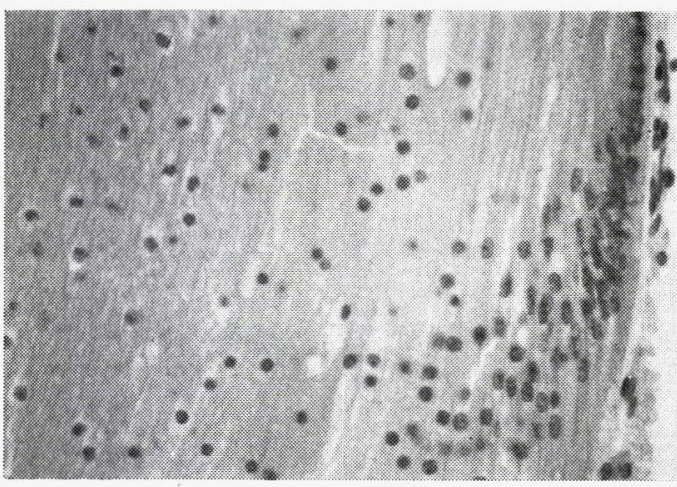

normal

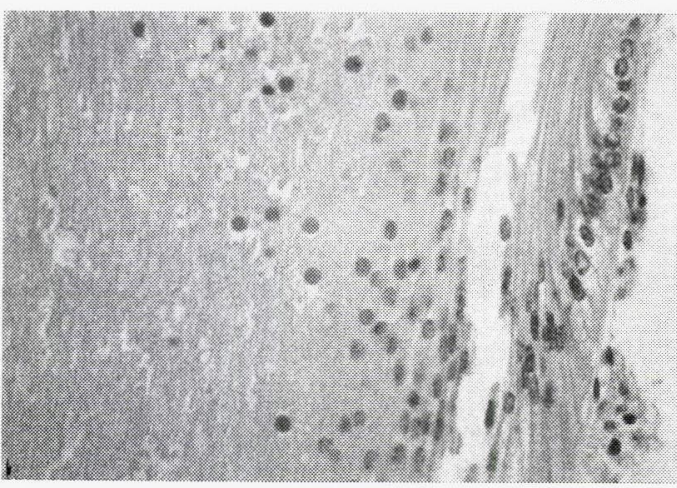

cataract

Fig. 3. Equatorial region of lens cortex Nuclei of lens fibers showing early disappearance in cataract mouse

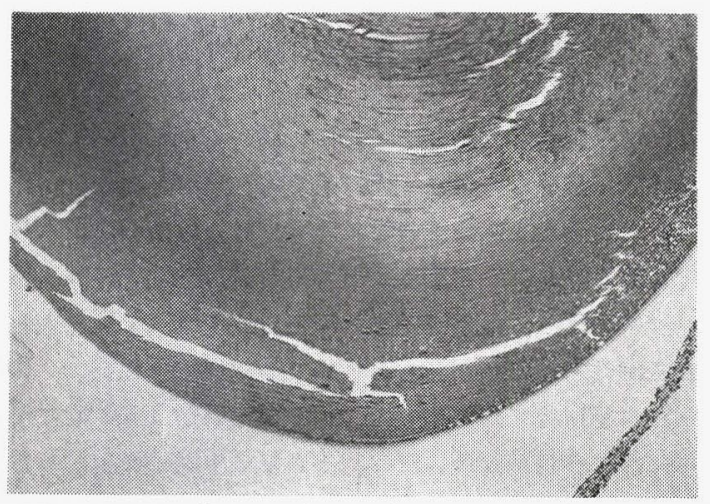

Fig. 4. Small vacuoles in lens cortex of cataract mouse

められた。

生化学的な検討では, 含水量は成長に伴い増加したも

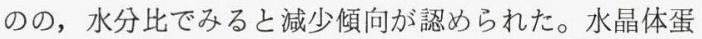
白については, 3 週秢までは水溶性蛋白が增加し, 不溶

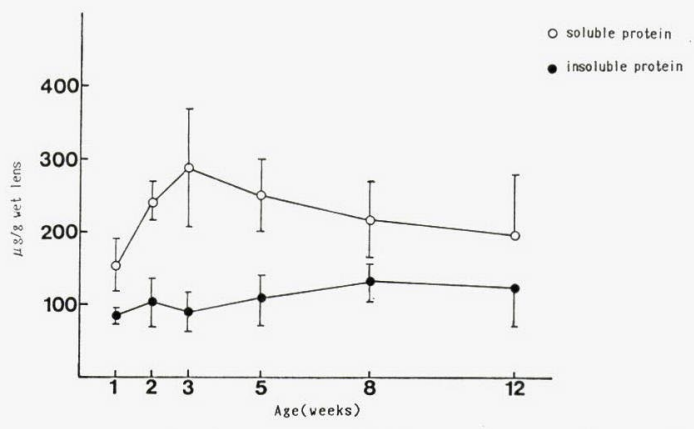

Fig. 5. Soluble and insoluble protein in lens of cataract mouse

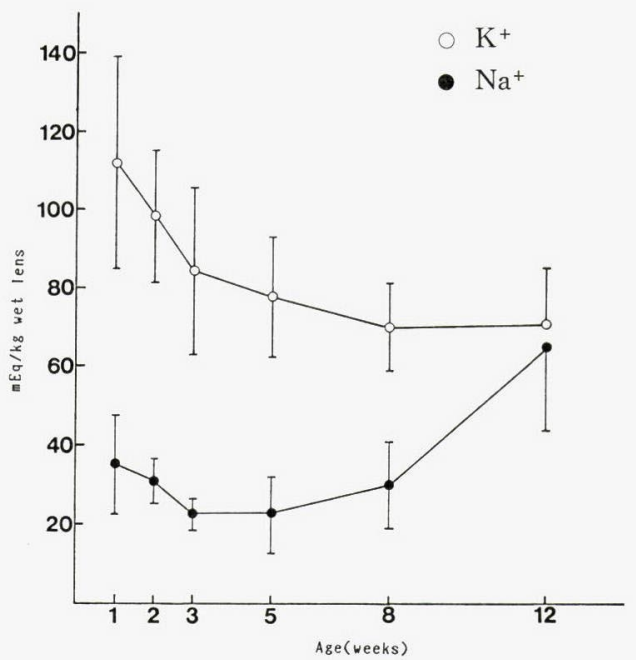

Fig. 6. Levels of sodium and potassium in lens of cataract mouse

性蛋白には余り変化は見られなかったが，5週龄以後， 水溶性蛋白の減少, 不溶性蛋白の軽度な增加が見られた (Fig. 5)。

$\mathrm{Na}^{+}, \mathrm{K}^{+}$量は, 5 週齢まで減少傾向を示したが， $\mathrm{Na}^{+}$ は 8〜12週齢にかけて増加し，12週齢では $\mathrm{Na}^{+}, \mathrm{K}^{+}$の 值がほぼ同程度となった（Fig. 6)。

Table 2 は，遺伝様式の検討のために行った交配実 験の成績を示したものであるが，今までに殆ど若齢時の 白内障の発症が見られていない IV CS 系， DBA/2 系 マウスとの交配F 1 では, 白内障個体は 1 例も出現しな かったが，そ机ぞれのF 1をCSM 系に戻し交配したと ころ，どちらの交配に扔いてす，それぞれ 10/46（21.7 $\%$ \%) 26/90（28.9\%）上約 $1 / 4$ 例が白内障を発症した。 これらの白内障の発症頻度についてはこれまで性差は認 
Table 2. Segregation of cataract upon crossing between CSM and another inbred mouse strain

\begin{tabular}{|c|c|c|c|c|c|c|}
\hline \multirow[t]{2}{*}{ Cross } & \multirow{2}{*}{$\begin{array}{l}\text { No, of } \\
\text { pairs }\end{array}$} & \multicolumn{2}{|c|}{$\begin{array}{l}\text { Phenotype of offspring } \\
\text { obs. (exp.) }\end{array}$} & \multirow[t]{2}{*}{ Total } & \multirow[t]{2}{*}{$x^{2}$} & \multirow[t]{2}{*}{$\mathrm{P}$} \\
\hline & & normal & cataract & & & \\
\hline$(\operatorname{IVCS} \times \mathrm{CSM}) \mathrm{F} 1$ & 6 & 46 & 0 & 46 & & \\
\hline$(\mathrm{DBA} / 2 \mathrm{Csk} \times \mathrm{CSM}) \mathrm{F} 1$ & 6 & 37 & 0 & 37 & & \\
\hline$\{(\mathrm{IVCS} \times \mathrm{CSM}) \mathrm{F} 1 \times \mathrm{CSM}\}$ & 4 & $36(34.5)$ & $10(11.5)$ & 46 & 0.26 & $>0.5$ \\
\hline$\{(\mathrm{DBA} / 2 \mathrm{Csk} \times \mathrm{CSM}) \mathrm{F} 1 \times \mathrm{CSM}\}$ & 10 & $64(67.5)$ & $26(22.5)$ & 90 & 0.73 & $>0.3$ \\
\hline
\end{tabular}

められていない。

\section{考 察}

白队障は，水晶体構成タンパクである水溶性の $\alpha$-クリ スタリンが変性し，不溶性アルブミノイド等に変化する ことによって起こる水晶体の混濁である。ヒトでは，先 天性白内障の他, 成人病の一つである糖尿病に併発する 糖㽷病性白内障，高齢化社会の進行に伴い増加している 老人性白内障などが問題となっている。

白内障のモデル動物としては，ラットなどを用いた実 験的なガラクトース白内障や，マウス，ラットを主とし た失天性白内障モデルの系統が幾つか報告されている $[1$, $3,13,16,18]$ 。

今回我々が検討した， CSM 系の白内障の発症時期に ついては, 肉眼的には既に開眼時 (12日鈴)に, 水晶体 の後極側と思われる部位に点状の白濁が認められている。 しかしながらこの白濁は，左右雨側に同時に発生するる のではなく，その進行状態も個体によって異なり，最初 からグレード 3 の混濁を示すものやグレード 1 のまま推 移するものなよ゙様々である。乙うした傾向は, 他の遺伝 性白内障モデルでも報告されて抢り, 白内障発症の原因 が遺伝子のみにより規定されているものではないことを 示していると思われる。

組織学的には, 生後 6 日秢で水晶体線維の核の脱核状 態にIV C S 系マウスとの間で差が見られ, IV C S 系で は, 核濃維を起こした後, 核クロマチンと思われる好塩基 性顆粒が，比較的深部まで認められるのに対し， CSM 系では, 核の円形化の後, 好塩基性は失われ好酸性の円 形物質となっていた。乙うした脱核過程の異常は，他の 白内障マウスでも報告されており, Cac マウスでは, 核 膜の破壊が生じにくいため，水晶体深部まで細胞核の残 存が認められている。乙の他, Philly マウスで, 核弓 部の核の增数あるいは消失の遅れが認められており $[4$ ，
15], Cad, Emory マウスでは核数の減少あるいは消失の 早まりが報告されている $[3,10]$ 。CSM 系の場合には， 光顕レベルでは，核クロマチンの消失の早まりと思われ る像が得られているが，核膜の名残と思われる好酸性小 体は, かなり水晶体深部まで認められるため, 現時点で は, 脱核異常が認められるというにとどめておくのが正 確かと思われる。12日秢以後に認められた, 皮質部浅層 に形成された空胞は, Emory マウスの報告 [14]に示さ れているものと類似していた。

生化学的な検討結果からは，加齢に伴って水晶体中の 不溶性蛋白, $\mathrm{Na}^{+}$の増加などが認められたが, $\mathrm{Cac}$ マウ スで報告されているほど著しい変化ではなかった。不溶 性蛋白は, 白内障の進行に連れ增加することが知られて いるが [11]，CSM 系の成績を見る限りでは，余り大 きな変化ではなく, $\mathrm{Na}^{+}$については $\mathrm{Cac}, \mathrm{Cts}$ 系マウス 等で白内障の進行とともに增加し, 本来高 $\mathrm{K}^{+}$, 低 $\mathrm{Na}^{+}$ である水晶体が高 $\mathrm{Na}^{+}$，低 $\mathrm{K}^{+}$になることが報告され ている $[8,9]$. CSM 系では $\mathrm{Na}^{+}, \mathrm{K}^{+}$の逆転現象は 見られなかったが，12週粭で $\mathrm{Na}^{+}, \mathrm{K}^{+}$量がほぼ同程度 となった。また水分含量の変化は, Cac マウスとは異な り, ほぼ正常マウスの範囲内にあり, これらの成績から $\mathrm{CSM}$ 系の白内障発症機序は Cac マウスで報告されて いるものとは異なっているあのと思われた。

マウスの白内障モデルとしては, Cac マウスが最むよ く研究されて抢り, 白内障の原因物質として, 水晶体内 に Na-K ATPase の阻害物質（ペプタイド）の存在が 確認されている $[7,9]$ 。この阻害物質により $\mathrm{Na}-\mathrm{K}$ イ オンの能動輸送系に異常が起こり, 水晶体内に $\mathrm{Na}^{+}$, $\mathrm{Ca}^{+}$が増加しこれに伴い, 含水量の増加, $\mathrm{SH}$ 化合物の 減少, 水晶体線維の膨化等が起こり, 水晶体の混濁に至 ると考えられている。

この他の白内障モデルとしては, Shrivelled (Cat ${ }^{\mathrm{Fr}}$ ) が比較的よく調べられており，Zwann et al. [19,20] は，水晶体核の核濃縮像に注目し，乙れが水晶体線維の 
変性につながる変化と考えている。また DDI 系マウス にみられている白内障の観察では, 電顕により通常では 6 力月齢以後に認吼る, 後皮質水晶体線維加ら水晶 体包に伸びる絾突起の形成 [17] が白内障マウスでは， 1 カ月から認められたとしている。さらに宇賀 [18］ら は, 遺伝的素因として，乙のマウスは水晶体上皮の viability が微弱で, 上皮が発生初期㳊過剩に分裂を繰り 返し viability を消耗したため, 本来, 後皮質に出現す るはずの加龄性変化が後皮質に到達する以前の早期に上 皮側で発現したという仮説を提唱している。

ての他にも，いくつかの白内障モデルマウスが報告さ れているが，その多くは形態学的な観察にとどまってお り, 白内障の発症原因まで研究が進んでいるものは少な い。

CSM 系の遺伝子支配については, Table 2 に示した とおり, IV CS, DBA / 2 系とのF 1 では全く発症例がな く，F1と CSM 系とのバッククロスでそれぞれ21.7\%， $28.9 \%$ 之約 $1 / 4$ の個体に発症が見られ，乙れらの成績は 2 個の劣性遗伝子が関与していると考えた時の期待值之 それほど矛盾しないあのと思われた。しかしながら CSM 系マウスは, まだ系統確立途上であり, 遺伝子の 固定は不十分と思われ，また遺伝子が 2 個以上の場合の 遺伝様式の解明には, 一層詳細な交配実験が必要と思わ れる。

白内障マウス系統として Cac, Philly などは劣性単一 遺伝子に支配されており，Cat ${ }^{\mathrm{Fr}}$, Emory などは優性単 一遺伝子に支配されている。また Cad は, 優性致死遺 伝子之劣性遺伝子の二重支配を受けているととが報告さ れている。以上に報告したように，CSM 系マウスは， 遺伝性白内障を若齢で発症し, 脱核異常, 空胞形成等に ついては, Emory マウス等の報告に見られるものと類 似の点ああるが, 症状, 遭伝様式などの点で他の白内障 マウスと異なり, 新しい白内障モデルマウスとして有用 と思われる。

\section{要 約}

当研究所で維持している SENCAR 系マウスの中から, 白内障を発症する個体が見いだされ，選抜交配の結果， 新たな系統 (CSM 系) として確立された。この系統に ついて, 遺伝学的, 組織学的, 生化学的検討を加えた。 遗伝学的には, 二つの劣性遺伝子が関与していると思わ れる成績が得られた。組織学的には, 水晶体線維の脱核 過程に異常が認められ，12日齢以後の個体で，水晶体赤 道部前後に小空胞の発生がみられた。生化学的には, 加 龄に伴う $\mathrm{Na}^{+}$の増加，不溶性蛋白の増加などが認めら
れた。

\section{文}

\section{献}

[1] Beasley, A. B. (1963). Inheritance and development of a lens abnormality in the mouse, J. Morph., $112,1-7$.

[2] Brown, E. R., Nakano, T., and Vankin, G. L. (1970). Early development of an inherited cataract in mice, Exp. Animals, 19, 95-100.

[3] Davidorf, F. and Eglitis, I. (1966). A study of a hereditary cataract in the mouse, J. Morph., 119, 89-100.

[4] Hamai, Y., Fukui, H. N., and Kuwabara, T. (1974). Morphology of hereditary mouse cataract, Exp. Eye Res., 18, 537-546.

[5] Iwata, S. and Kinoshita, J. H. (1971). Mechanism of development of hereditary cataract in mice, Invest. Ophthalmol., 10, 504-512.

［6］岩田修造（1978）。遗伝性白内障マウス（その1). 臨眼, 32, 344-348

［7］岩田修造（1978），遗伝性白内障マウス（その2), 臨眼, 32, 474-478.

[8] 岩田修造 (1982). 白内障に関する諸問題. 日眼会誌，86, 109-133.

[9] Kinoshita, J. H. (1976). 白内障発生に関する生化学的 考察. 日眼会誌, 80, 78-87.

[10] Kuck, J. F. R., Kuwabara, T., and Kuck, K. D. (1981/1982). The Emory mouse cataract : an animal model for human senile cataract. Current Eye Res., 1, 643-649.

[11] Kuck, J. F. R. and Kuck, K. D. (1983). The Emory mouse cataract: Loss of soluble protein, glutathione, protein sulfhydryl and other changes. Exp. Eye. Res., 36, 351-362.

[12] 黒木登志夫 (1982). SENCAR マウス. 代謝（臨時増刊 号 癌 '82)，19，1101-1107.

［13］大鳥 寛・吉田豊彦・狗田忠義 (1968). マウスの小眼症 をともなう遗伝的白内障について。実験動物，17，91-96.

[14] 滝沢㵓子・葉 隆一・石樹敏・佐々木一之 (1985). EMORY マウス白内障の形態学的研究. あたらしい眼科, 2, 1269-1271.

[15] Uga, S., Kador, P. F., and Kuwabara, T. (1980). Cytological study of Philly mouse cataract. Exp. Eye Res., 30, 79-92.

［16］宇賀茂三・小原真樹夫・石川 哲（I981），優性遺伝性 又 ウス (Cts 系) 白内障の成因に関する形態学的研究. 旦眼 会誌, 85, 53-64.

[17] 宇賀茂三・小原真樹夫・石川哲 (1982). マウス水晶体 の加齢に関する形態学的研究. 日眼会誌，86, 223-230.

[18］宇賀茂三・小原真樹夫・Bensaoula, T., 石川 哲・中野 健司 (1984). DDI 系マウス白内障の発生機序に関する形 態学的研究. あたらしい眼科. 1，88-93.

[19] Zwann, J. and Williams, R. M. (1962). Morphogenesis of the eye lens in a mouse strain with hereditary cataract. J. Exp. Zool. 169, 407-421.

[20] Zwann, J. and Williams, R. M. (1969). Cataract and abnormal proliferation of the lens epithelium in mice carrying the $\mathrm{Cat}^{\mathrm{Fr}}$ gene. Exp. Eye Res., 8, 161-167. 